\title{
Preliminary report of fission track studies in the Jameson Land basin, East Greenland
}

\author{
Kirsten Hansen
}

Fission track (FT) analysis is especially suited to reveal and date low temperature events. The closure temperature of apatite $\left(100 \pm 30^{\circ} \mathrm{C}\right)$ and its annealing characteristics in the interval of $70-125^{\circ} \mathrm{C}$ are especially relevant to the study of the maturation of hydrocarbons (Gleadow et al., 1983).

FT analyses were made on Permian to Cretaceous, quartzose sandstones and arkoses from the Jameson Land basin. Both FT ages and track length distributions for apatites were obtained for samples taken along the western and eastern margin of the basin (fig. 1 and Table 1) in order to study the tectonic and thermal history of the area. The investigation takes advantage of earlier FT work in the neighbouring Caledonian mountain belt which is believed to be the source of the terrigenous material, including the apatites, which make up the sediments (Hansen, 1985). A report of further investigations in this area is in preparation.

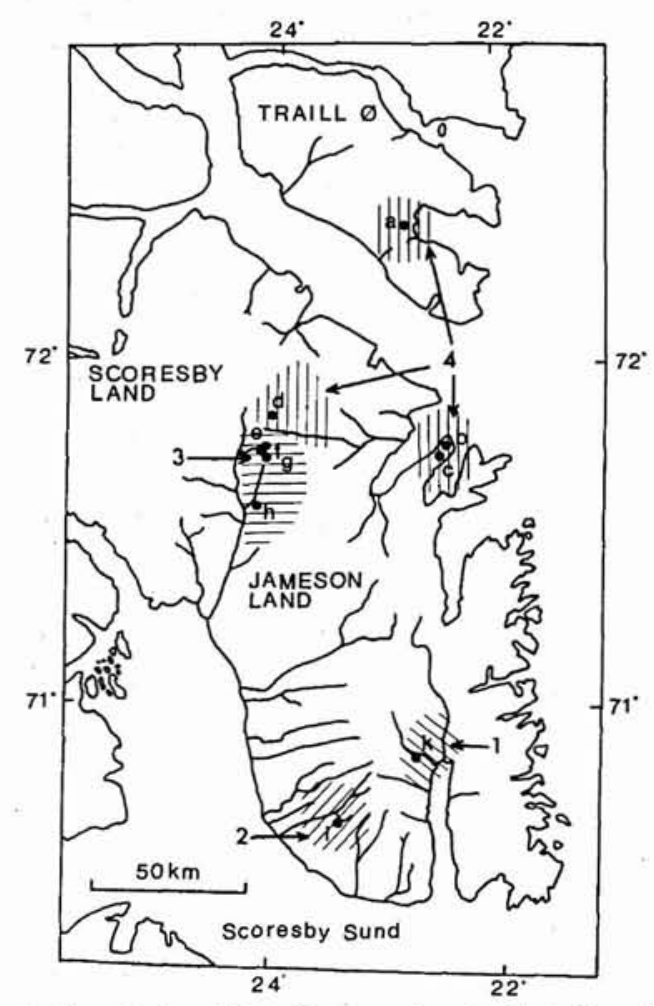

Fig. 1. Sample localities, Jameson Land, East Greenland. Shadings indicate different thermal type areas. Key to localities in Table 1.

\section{Technique}

Samples of $c$. half a kilogram were crushed and separated using magnetic and heavy liquid methods. Most samples yielded apatites. Polished and etched apatite mounts were irradiated together with mica detectors in the $\mathrm{J} 1$ facility of the HERALD reactor in Aldermaston, England, for age determinations. Specially polished and etched mounts were prepared for track length measurements. The measurements were carried out using a Zeiss-Jena microscope with a $\times 100$ oil objective and a cover slip, and either a calibrated net or a scale bar inserted in the $\times 12.5$ ocular. The calibration used in the age determinations follows the suggestions of Hurford \& Green (1983). The NBS SRM612 and Corning $\mathrm{CN} 1$ and $\mathrm{CN} 2$ glasses were t.sed as fluence monitors and the Fish Canyon and Mt. Dromedary apatites as age standards in the zeta calibration.

\section{Results}

Table 2 shows results of FT apatite age determinations and mean track length distributions. Table 3 shows track densities for glass standards for the two irradia-

Table 1. Basic data for sample localities, Jameson Land, East Greenland

\begin{tabular}{lccc}
\hline Locality & $\begin{array}{l}\text { area } \\
\text { type }\end{array}$ & $\begin{array}{c}\text { GGU } \\
\text { sample no. }\end{array}$ & $\begin{array}{c}\text { elevation sediment } \\
\text { m a.s.l. formation age }\end{array}$ \\
\hline
\end{tabular}

\begin{tabular}{|c|c|c|c|c|}
\hline \multicolumn{5}{|l|}{ Traill $\varnothing$} \\
\hline \multicolumn{5}{|c|}{ Wegener Halve } \\
\hline b & 4 & 298343 & 490 & Triassic \\
\hline c & 4 & 327546 & 880 & Permian \\
\hline \multicolumn{5}{|c|}{ West Jameson Land } \\
\hline d & 4 & 221247 & 1100 & Upper Permian \\
\hline e & 3 & 292005 & 900 & Upper Permian \\
\hline f & 3 & 248628 & 400 & Lower Permian \\
\hline g & 3 & 293284 & 771 & Upper Permian \\
\hline $\mathrm{h}$ & 3 & 293252 & 213 & Lower Triassic \\
\hline \multicolumn{5}{|c|}{ South Jameson Land } \\
\hline $\mathrm{i}$ & 2 & 292016 & 300 & Upper Jurassic \\
\hline \multicolumn{5}{|c|}{ Ugle Elv, east Jameson Land } \\
\hline k & 1 & 248652 & 500 & Upper Jurassic \\
\hline
\end{tabular}

Deposition ages are obtained from Piasecki (personal communication, 1987). 
Table 2. Mean track lengths and apatite fission track ages of sedimentary rocks from the Jameson Land basin, East Greenland

\begin{tabular}{|c|c|c|c|c|c|c|}
\hline $\begin{array}{l}\text { Sample } \\
\text { GGU no. }\end{array}$ & $\begin{array}{l}\text { Irr. } \\
\text { no. }\end{array}$ & $e_{3} \times 10^{5}\left(N_{s}\right)$ & $e_{i} \times 10^{5}\left(N_{i}\right)$ & $\begin{array}{c}\text { grain } \\
\text { no. }\end{array}$ & $\begin{array}{l}\text { age(Ma) } \\
\quad \pm 1 \sigma\end{array}$ & $\begin{array}{c}\text { mean length }(\mu \mathrm{m}) \\
\quad \pm 1 \sigma(\mathrm{N})\end{array}$ \\
\hline \multicolumn{7}{|l|}{ Traill $\varnothing$} \\
\hline 327371 & KH18 & $7.4369(160)$ & $51.500(1108)$ & 7 & $\begin{array}{r}15.57 \\
\pm 1.69\end{array}$ & $\dagger$ \\
\hline \multirow{2}{*}{\multicolumn{2}{|c|}{$\begin{array}{l}\text { Wegener Halvo } \\
298343\end{array}$}} & & & & & \\
\hline & & & & $\dagger$ & $\dagger$ & $\begin{array}{l}12.28 \\
\pm 3.34(44)\end{array}$ \\
\hline 327546 & KH18 & $5.2455(86)$ & $29.643 \quad(486)$ & 9 & $\begin{array}{r}19.23 \\
\pm 2.59\end{array}$ & $\begin{array}{l}10.64 \\
\pm 3.76(33)\end{array}$ \\
\hline \multicolumn{7}{|c|}{ West Jameson Land } \\
\hline 221247 & KH18 & 7.4746 ( 31$)$ & $40.025(166)$ & 4 & $\begin{array}{r}20.29 \\
\pm 4.20\end{array}$ & $\begin{array}{l}10.83 \\
\pm 3.20(28)\end{array}$ \\
\hline 292005 & KH17 & $57.029(340)$ & $50.320(300)$ & 8 & $\begin{array}{r}135.56 \\
\pm 14.01\end{array}$ & $\begin{array}{l}10.01 \\
\pm 2.49 \text { ( } 37)\end{array}$ \\
\hline $248628 *$ & KH17 & 25.658 & 45.290 ( 496) & 8 & $\begin{array}{r}70.23 \\
\pm 9.49\end{array}$ & $\begin{array}{l}10.55 \\
\pm 2.95(110)\end{array}$ \\
\hline 293284 & KH18 & $8.2379(71)$ & $8.0058(69)$ & 7 & $\begin{array}{r}111.10 \\
\pm 20.19\end{array}$ & $\dagger$ \\
\hline 293252 & KH17 & $29.628(432)$ & $45.677(666)$ & 9 & $\begin{array}{r}77.93 \\
\pm 7.05\end{array}$ & $\begin{array}{l}10.05 \\
\pm 2.75(100)\end{array}$ \\
\hline \multicolumn{2}{|c|}{ South Jameson Land } & & & & & \\
\hline 292016 & KH17 & $15.630(472)$ & 34.406 (1039) & 15 & $\begin{array}{r}54.68 \\
\pm 4.71\end{array}$ & $\begin{array}{l}11.51 \\
\pm 2.30(100)\end{array}$ \\
\hline \multicolumn{3}{|c|}{ Ugle Elv, east Jameson Land } & & & & \\
\hline $248652 *$ & KH18 & $29.176(467)$ & 16.931 ( 271) & 10 & $\begin{array}{r}205.30 \\
\pm 31.39\end{array}$ & $\dagger$ \\
\hline
\end{tabular}

* failed the chi-squared test. Ages calculated on the basis of individual grain $\varrho_{s} / \varrho_{i}$ ratios. $\dagger$ not determined.

$\varrho_{s}$ and $\varrho_{j}$ are track densities of spontaneous and induced tracks respectively, $N_{3}$ and $N_{1}$ similarly are the number of tracks counted and $\mathrm{N}$ represents the number of tracks measured.

tions and the zeta values which were employed. Fig. 2 shows the measured track length distributions.

\section{Discussion}

Apatite FT ages, except for the area in the south-east which is described below, are annealing ages modified by a post-sedimentary heating event (Table 2). This is shown by FT ages which are younger than the $150 \mathrm{Ma}$ apatite cooling ages found for the neighbouring basement (Hansen, 1985) and also younger than the sediment deposition age of individual samples given in Table 1. The FT age distribution suggests that different parts of the area suffered different heating histories. The different parts of the area are shown in fig. 1 and are described below.

(1) Area type 1 is an area in the south-east which is only weakly annealed and probably slowly uplifted. It gives an apatite FT age of $c$. $200 \mathrm{Ma}$. The material for the sample representing this area may originate from the nearby Hurry Inlet granite of 425 Ma (Hansen \&
Steiger, 1971). The FT age for the granite yields $203 \mathrm{Ma}$ for apatite for a surface sample (Gleadow \& Brooks, 1979) taken to represent apatite FT ages at today's erosion level for the Hurry Inlet granite. This means that apatites in the sediment may range from 425 to 200 Ma for an unannealed sample. The actual age spread found for the sediment (Upper Jurassic) is between 80 and $330 \mathrm{Ma}$, i.e. lower than expected for unannealed samples, the youngest being younger than the sediment age indicating that the partial annealing was experienced after deposition. The mild annealing suggests that the temperature was close to the lower temperature limit of the annealing interval, e.g. c. $80^{\circ} \mathrm{C}$, which is in accordance with vitrinite reflectance measurements found for the area (E. Thomsen, personal communication, 1987).

(2) Area type 2 is an area in the south which was probably almost totally annealed (close to $125^{\circ} \mathrm{C}$ ) and was slowly uplifted at, or later than $55 \mathrm{Ma}$ ago, the thermal activity perhaps being indirectly related to the Scoresby Sund igneous activity at 53-56 Ma (Watt et al., 1986). A 


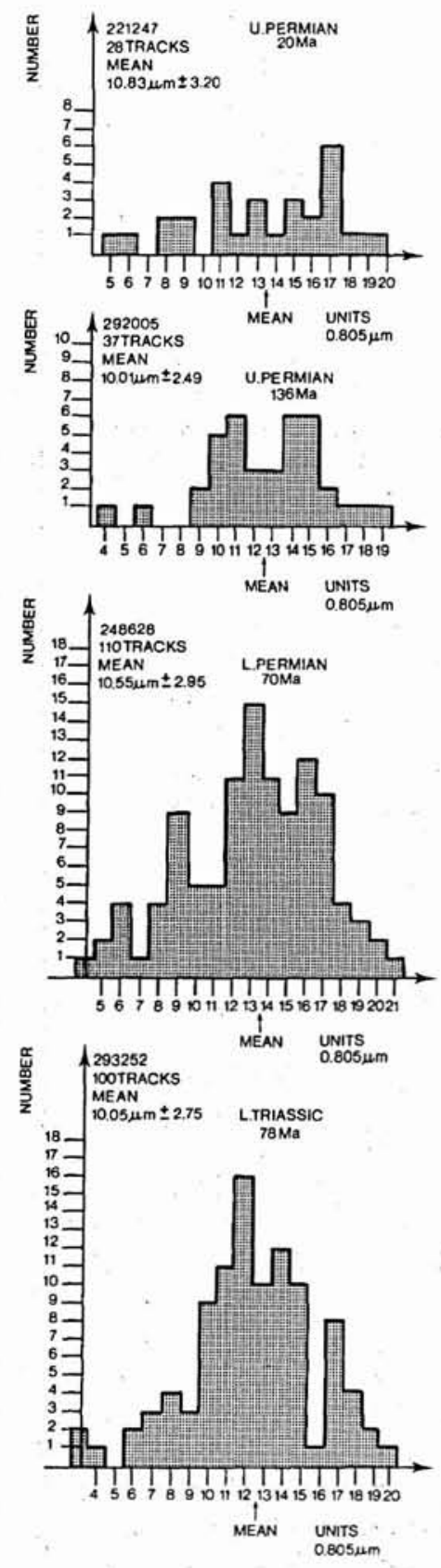

temperature not much lower than $125^{\circ} \mathrm{C}$ fits the maturity pattern revealed by, e.g. reflectance measurements (E. Thomsen, personal communication, 1987). This area could be related to the partly annealed area of type 3 , representing a more deeply buried section.

(3) Area type 3 in the west shows varying ages, 70-135 $\mathrm{Ma}$, which can be partly ascribed to different degrees of annealing due to different elevations (Table 1). Thus the samples from the highest levels cooled below the an-
Fig. 2. Track length distributions, Jameson Land, East Greenland. Mean track lengths, uncertainties, deposition ages and apatite fission track ages are also given in the figure.

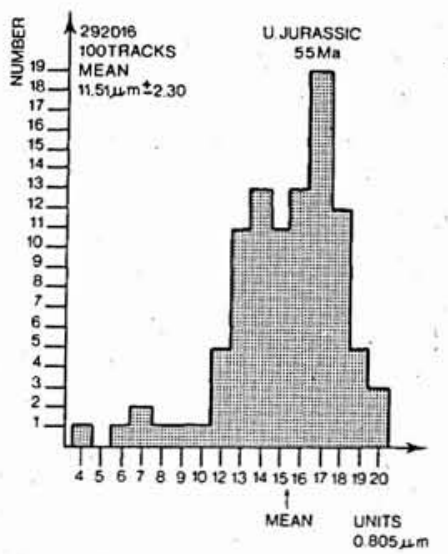

nealing interval first and also did not proceed so far into the annealing interval. Temperature differences at $30^{\circ} \mathrm{C} / \mathrm{km}$ would be $c .15-20^{\circ} \mathrm{C}$ for differences in altitudes of $c .600 \mathrm{~m}$ which could produce marked age differences at temperatures around $100^{\circ} \mathrm{C}$ (Gleadow et al., 1983). The time of the uplift may coincide with the uplift of the southern area. Hydrocarbon maturity measurements reveal a complex pattern with a major maturity shift between Lower and Upper Permian (Surlyk et al., 1986) not found in the FT data. 
(4) Area type 4 in the north shows young uplift ages of $c$. $20 \mathrm{Ma}$ which implie almost total annealing. The connection between the eastern and western part is unclear, as is the influence of the Werner Bjerge intrusion which also gives an apatite uplift age of $20.5 \mathrm{Ma}$ (Gleadow \& Brooks, 1979) and similar K-Ar ages (Schassberger, personal communication to C. K. Brooks). Maturity measurements also show these northern areas to be post-mature with respect to oil generation (Surlyk et al., 1986).

The above findings are supported by track length distributions, mean track lengths, and their uncertainties (Table 2 and fig. 2). Heating into the annealing interval reduces track lengths, the track length distribution thus being diagnostic of the path through the heating interval (Gleadow et al., 1986).

Track length distributions have so far been obtained for samples from the southern area (type 2), the western area (type 3 ), and the northern areas (type 4), although the restricted amount of material makes it difficult to obtain reliable results. However, the internal consistency of the few data allows a generalised description of track length distributions for three of the areas described.

The youngest area (type 4) shows the simplest track length distributions in its eastern part, where distributions are dominated by young tracks in a typical skewed uplift pattern (Gleadow et al., 1986). However, the broad distribution and the low mean indicate a small admixture of pre-uplift age to the measured age. This means, as suggested above, that temperatures close to total annealing $\left(125^{\circ} \mathrm{C}\right)$ were attained together with late uplift (after $20 \mathrm{Ma}$ ago). The distribution for the sample taken close to the contact of Werner Bjerge intrusion (221247) does not reveal a typical uplift pattern. This may, however, be due to the difficult and restricted material and interpretation must await further determinations.

The track length distribution of the northern samples (area type 4) contrasts with the distribution for the western area (type 3) which shows a very broad symmetrical pattern. A symmetrical distribution is characteristic of partial annealing with only a small proportion of newly formed long tracks, i.e. the resulting mixed age is dominated by partly annealed old tracks and the uplift age is much younger than the mixed age. A temperature close to $100^{\circ} \mathrm{C}$ must be assumed as the maximum temperature experienced.

In the southern area (type 2) the track length distribution is narrower with a younger ( $55 \mathrm{Ma}$ ) age compared to the western area, but it still has an old component as shown by mean lengths and uncertainties; it is probably
Table 3. Track density of glass standards, calibration factors

\begin{tabular}{lccc}
\hline & $\begin{array}{c}\varrho_{d} \text { SRM612 } \\
\text { Number }\end{array}$ & $\begin{array}{c}\varrho_{d} \mathrm{CN1} \\
\text { Number }\end{array}$ & $\begin{array}{c}\varrho_{\mathrm{d}} \mathrm{CN} 2 \\
\text { Number }\end{array}$ \\
\hline KH17 & $8.089194 \times 10^{5}$ & $24.86787 \times 10^{5}$ & $22.96979 \times 10^{5}$ \\
5242 & 6446 & 5954 \\
KH18 & $7.100035 \times 10^{5}$ & $21.90888 \times 10^{5}$ & $21.64268 \times 10^{5}$ \\
& 4601 & 5679 & 5610 \\
$\zeta$ & $288 \pm(9.38 \%)$ & $101 \pm(4.95 \%)$ & $105 \pm(4.76 \%)$ \\
\hline
\end{tabular}

KH17 and KH18 are irradiation numbers, $\varrho_{\mathrm{d}}$ track densities of mica detectors for the respective glass standards and zeta calibration factors (Hurford \& Green 1983) used for the age determination based on age standards.

a result of further annealing due to deeper burial than found in the western area. This implies a temperature close to, but not exceeding, $125^{\circ} \mathrm{C}$ and a slow uplift, not much later than $55 \mathrm{Ma}$ ago. The area has been uplifted together with the neighbouring areas which were never so deeply buried, as shown by their higher ages and greater spread in track lengths.

\section{Conclusions}

In general the results support the maturity pattern found for the area by Surlyk et al. (1986). Assuming a geothermal gradient of $30^{\circ} \mathrm{C} / \mathrm{km}$, the maximum burial is constrained to be less than $3 \mathrm{~km}$ by by the maximum temperature experienced (less than $c .125^{\circ} \mathrm{C}$ ), except perhaps to the north. During uplift, sediments in the southern part first passed the $100^{\circ} \mathrm{C}$ isotherm not much later than $55 \mathrm{Ma}$ ago and were uplifted together with the less deeply buried neighbouring areas. To the north, uplift led to the passing of the $100^{\circ} \mathrm{C}$ isotherm much later, around $20 \mathrm{Ma}$ ago. The reasons for the young ages to the north, compared to more southern areas could be delayed uplift followed by a rapid uplift during the last $20 \mathrm{Ma}$. The rapid uplift is not likely to have proceeded for a longer time span than the $20 \mathrm{Ma}$ as this would lead to exposure of sedimentary rocks of higher formation age to the north compared to the rest of the area, and this did not occur. Alternatively, younger ages could also result from a higher geothermal gradient which would be likely to accompany the Tertiary intrusive activity. Finally a combination of the two explanations is possible.

Acknowledgements. This study was supported by the Nordic Council of Ministers and the Danish Natural Science Research Council. The Geological Survey of Greenland supplied the samples. I am especially grateful to S. Piasecki (Geological 
Survey of Greenland, Denmark) for his help during the work. Age standards were supplied by C. W. Naeser (USGS Denver, USA) and A. J. W. Gleadow (University of Melbourne, Australia). Corning glasses were supplied by Corning Glass Works, USA. C. K. Brooks (University of Copenhagen, Denmark) and F. Surlyk (Geological Survey of Greenland) contributed valuable comments on the manuscript.

\section{References}

Gleadow, A. J. W. \& Brooks, C. K. 1979: Fission track dating, thermal histories and tectonics of igneous intrusions in East Greenland. Contr. miner. Petrol. 71, 45-60.

Gleadow, A. J. W., Duddy, I. R. \& Lovering, J. F. 1983: Fission track analysis: a new tool for evaluation of thermal histories and hydrocarbon potential. J. Aust. Petrol. Explor. Ass. 23, 93-102.

Gleadow, A. J. W., Duddy, I. R., Green, P. F. \& Lovering, J. F. 1986: Confined fission track lengths in apatite: a diagnostic tool for thermal history analysis. Contr. miner. Petrol. 94, 405-415.

Hansen, B. T. \& Steiger, R. H. 1971: The geochronology of the Scoresby Sund area 1: Rb-Sr mineral ages. Rapp. Gronlands geol. Unders. 37, 55-57.
Hansen, K. 1985: Fission track age determinations of vertical movements in the crust caused by continental rifting: A fission track age study of the Scoresby Sund area; method and results. Unpublished thesis, Univ. Copenhagen, 119 pp.

Hurford, A. J. \& Green, P. F. 1983: The zeta age calibration of fission track dating. Isotope Geosci. 1, 285-317.

Surlyk, F., Hurst, J. M., Piasecki, S., Rolle, F., Scholle, P. A., Stemmerik, L. \& Thomsen, E. 1986: The Permian of the western margin of the Greenland Sea - A future exploration target. In Halbouty, M. T. (edit.) Future petroleum provinces of the world. Mem. Am. Ass. Petrol. Geol. 40, 629659.

Watt, W. S., Larsen, L. M. \& Watt, M. 1986: Volcanic history of the lower Tertiary plateau basalts in the Scoresby Sund region, East Greenland. Rapp. Grønlands geol. Unders. 128, 147-156.

\title{
Studies of the onshore hydrocarbon potential in East Greenland 1986-87: field work from $73^{\circ}$ to $76^{\circ} \mathrm{N}$
}

\author{
C. Marcussen, P.-H. Larsen, H. Nøhr-Hansen, H. Olsen, \\ S. Piasecki and L. Stemmerik
}

The study of the Devonian to Cretaceous sequence in central and northern East Greenland was continued in 1987. Field work was carried out from early July to mid August covering the region between Ymer $\emptyset$ and Hochstetter Forland (fig. 1). This was the second year of a two-year field work programme (Marcussen et al., 1987) which forms part of a regional programme comprising sedimentological, stratigraphic, structural, and petroleum geological studies of the sedimentary basin in central East Greenland (e.g. Surlyk, 1983; Surlyk et al., 1984, 1986a,b).

Stordal in Hudson Land, which offers a natural landing strip for STOL aircraft, was used as base camp for the 1987 expedition. The expedition group of 15 included four to five geological field parties and five supporting personnel, including a helicopter pilot and mechanic. In addition a five-man British-Danish East Greenland 'vertebrate-paleontological' expedition (Bendix-Almgreen, 1988) and a group from GGU plan- ning the 1988 expedition to North-East Greenland were present. Two teams (led by P.-H, Larsen and H. Olsen) studied the tectonics and sedimentology of the Devonian succession. Two teams (led by L. Stemmerik and S. Piasecki) investigated the Carboniferous, Permian and Triassic sedimentology of the region. The Jurassic and Cretaceous sequences were studied by two teams (led by S. Piasecki and in the late half of the season by $\mathrm{H}$. Nøhr-Hansen). All the teams collected material for source rock analyses and a large number of samples were also collected for determining reservoir rock properties.

\section{Devonian}

Sedimentological studies. The field work in 1987 was concentrated on Ymer $\emptyset$, Gauss Halv $\varnothing$, Moskusokselandet and Strindberg Land (figs 1, 2). Detailed facies analyses were made by vertical facies logging and 2- 